\title{
Examination of Soft-Heating Hyperthermia Exciting Composition with a Plane Type Spiral Coil
}

\author{
T. Maruyama, T. Takura, F. Sato, H. Matsuki, S. Aiba*, and T. Sato** \\ Department of Electrical and Communication Engineering, Graduate School of Tohoku University, 6-6-05 Aoba, Aramaki, Aoba-ku, \\ Sendai, Miyagi, 980-8579, Japan \\ * Department of Medical Science, Graduate School of Tohoku University, 2-1 Seiryo, Aoba-ku, Sendai, Miyagi, 980-8575, Japan \\ ${ }^{* *}$ NEC TOKIN Corporation, 6-7-1 Koriyama, Taihaku-ku, Sendai, Miyagi, 982-8510, Japan
}

\begin{abstract}
Hyperthermia is a therapeutic method that necrotizes cancer tumora by heating. We developed an implantable heat element for tumors, which is excited by applying an external magnetic field. The previously proposed soft-heating method of hyperthermia features the use of thermosensitive ferrite as the heat element. This means that the heat element can control the temperature automatically by referring to the Curie temperature of the thermosensitive ferrite. The heat element consists of a thermosensitive ferrite and a metal ring. For wrapped around the ferrite to increase the heat quantity. For application to superficial tumors, the utility of a plane-type spiral coil was examined. As a result, it was confirmed that the influence of the magnetic gradient in excitation does not greatly influence the temperature characteristic. Moreover, arranging the magnetic ferrite in a plane-type coil is effective in easing the excitation current value and the directivity of the magnetic flux.
\end{abstract}

Key words: hyperthermia, soft heating method, thermosensitive ferrite, plane-type spiral coil, solenoid coil

\section{平面型コイルを用いたハイパーサーミア励磁構成に関する検討}

\author{
丸山赴・田倉哲也・佐藤文博 ・松木英敏・相場節也 ${ }^{*} \cdot$ 佐藤忠邦** \\ 東北大学大学院工学研究科, 宮城県仙台市青葉区荒巻字青葉 6-6-05（广980-8579）

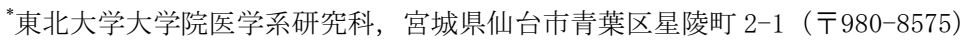 \\ *NEC トーキン株式会社，宮城県仙台市太白区郡山 6-7-1（テ982-8510）
}

\section{1. はじめに}

現在日本において，癌による死亡率が第 1 位を占めている. 発 癌率は 60 歳を越えてから急激に増えることから, 高齢化社会を迎 えた現在, 発癌者, 癌による死亡者は増えつづけ, 2015 年には年 間 89 万人が癌に罹患することが予想されている. その治療法とし ては, 手術や化学療法, 放射線療法を行うことが一般的である. また, 通常の治療法では治すことが難しい局所進行癌や再発癌に 対しては、ハイパーサーミア等の温熱療法が注目されている.

ハイパーサーミアは癌組織が，正常組織より熱に弱いことを利 用した治療法である. 正常組織は約 $44{ }^{\circ} \mathrm{C}$ で生存率低下が起こるの に対し, 癌組織は約 $42.5{ }^{\circ} \mathrm{C}$ で生存率が低下寸る. 正常組織では, 癌組織と同じように温められても，血流の影響が強いため，発熱 を抑えることができる. しかし, 癌組織の中にある血管は温めら れても拡張することができず, 癌組織のみが温められ死滅する.

ハイパーサーミアでは様々な加温方式が提案されている. その 中でも本研究では, 加温方式としてソフトヒーティング法1) 2) 3)を 用いている. その特徵として素子自身が温度制御機能を保有し， 過度な加温を避けることができるという利点を持つ. 広域的な腫 瘍組織に対してハイパーサーミアを適用寸る場合，血流の影響が 強、場合や広範囲に腫瘍が存在している場合は範囲致死温度まで 達しない部分が存在する可能性がある，そこで癌組織全体を完全 に壊死させることができる温度にまで高温にし，外科的効果をも 狙った高温ハイパーサーミア4) 5) 6)が提案されている. 高温ハイパ 一サーミアは, ソフトヒーティング法を応用したものであり, 自 己制御機能と高発熱の両方を実現している.

本研究における加温方式の適用可能範囲は磁場が届く範
囲すべてであり，脳腫瘍，肝腫瘍，膵癌などの深部腫瘍， 皮膚腫瘍の表在性腫瘍など多岐に渡る。本研究では, 適用 可能な一例として, 表在性腫瘍を取り上げる，表在性腫瘍 では, 腫瘍が浅部に存在するため, 励磁構成としては, 深 部腫瘍をターゲットとした場合と比べると比較的簡素なも のでよいといった利点が存在する. そのため, 平面型スパイ ラルコイルによって, 小型励磁構成を実現し, 浅部に磁界を発生 させる構成法についてコイル試作，発熱素子の発熱特性の検証， 磁性体配置による磁束の指向性に関して検討を行い, 簡素で携帯 可能な励磁システムの構築を目指している. なお, 浅部を表皮か ら $10 \mathrm{~mm}$ 程度までの表面上のものと定義するものとする.

\section{2. ソフトヒーティング法と高温ハイパーサーミア}

ソフトヒーティング法は常温近傍の比較的低い 温度領域にキュ リー温度をもち, かつヒステリシス損の大きい磁性材料を発熱体 として利用する. そしてこの磁性材料を高周波交番磁界の中に設 置して励磁し, 発生するヒステリシス損を発熱源としている. 磁 性体の温度がキュリー温度以上になると自発磁化が失われ, 急激 にその実効透磁率は減少する. そのことによって, 磁生体に磁束 の集中の有無が起こる．また，高温ハイパーサーミアを実現する ためには，より大きな発熱を得る必要があるため，磁生体を金属 環で取り巻いた複合型構造の発熱体を利用している.この複合型 発熱体を高周波磁界で励磁すると金属環に誘導電流が流れ, 短絡 電流損が生じこれが主な発熱源となる.この短絡電流損は非常に 大きいため, 高温ハイパーサーミアを行う上で非常に有効である. この高温ハイパーサーミアでは, 複合型素子を中心に加温範囲が 
広がることから，局所的な加温が可能である．これによって，正 常組織への影響を最小限に抑えつつも癌組織を死滅させることが 可能である.

Fig. 1 に温度制御の原理を示す. 磁心温度がキュリー温度 (以 下 Tc とする）以下の場合, 磁束が磁生体に集中し金属環には誘導 電流が流れ, 短絡電流損が生じる. しかし磁心温度が Tc を超える と磁性体の自発磁化が失われ，磁束の集中がなくなるため，短絡 電流損は非常に小さいものとなる. そして再ひ磁心温度が Tc を超 えると磁束を集中することとなり, 発熱する. すなわち Tcの值を 必要とする温度に設定することで発熱を自動的に制御が可能とな る . また, Fig. 2 に複合型発熱素子の概観を示寸.

\section{3. 実験}

\section{1 励磁方式}

発熱素子の励磁には，主にソレノイドコイルによる励磁 ( Fig. 3 ）と平面型コイルによる励磁 ( Fig. 4 ) が考えられる. 前者の場 合は, 体の一部もしくは全体が必ずコイル内部に入る. そのため, 患者一圧迫感を与えることが懸念される. しかし，後者の場合， 患部に発熱素子を埋め込み, 素子を埋め込んだ部位に平面型コイ ルを配置するだけであるため, , 圧迫感は減少すると考えられる. 特に表在性腫瘍などの体の浅部への励磁の場合は, 素子, コイル 間の距離が短いため, 平面型コイルによる励磁も容易となる.

また, 使用した発熱体は感温フェライト $\left(\mu \mathrm{r}: 3500, \mathrm{Tc}: 70{ }^{\circ} \mathrm{C}\right.$, $0.6 \times 0.6 \times 10 \mathrm{~mm}$ square type) に銅環 (厚さ $0.05 \mathrm{~mm}$ ) を巻 きつけたものである. この励磁条件に対する到達温度の特性を Fig. 5 に示す. Fig. 5 の横軸に周波数と磁束密度の積を示してある. こ れは，この発熱素子の主な発熱源が短絡電流によるものであり， 周波数の 2 乗と磁束密度の 2 乗に比例することから，この值を一 つの基準とした. この特性からこの発熱素子の励磁条件としては 200 付近から, 特性が向上寸るため, 励磁素子の最低条件として は $f[\mathrm{kHz}] \times B[\mathrm{mT}]$ が 200 を超えることを目標としている.

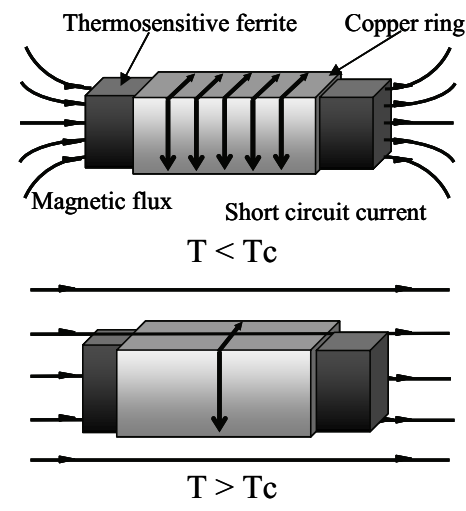

Fig. 1 Principle of heating.

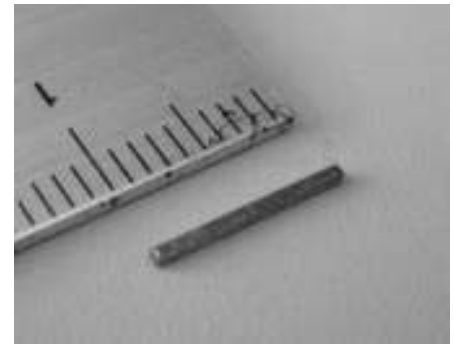

Fig. 2 Complex type of heat element.

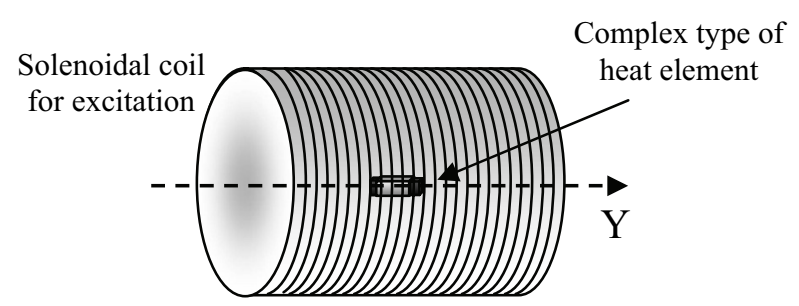

Fig. 3 Excitation with a solenoidal coil

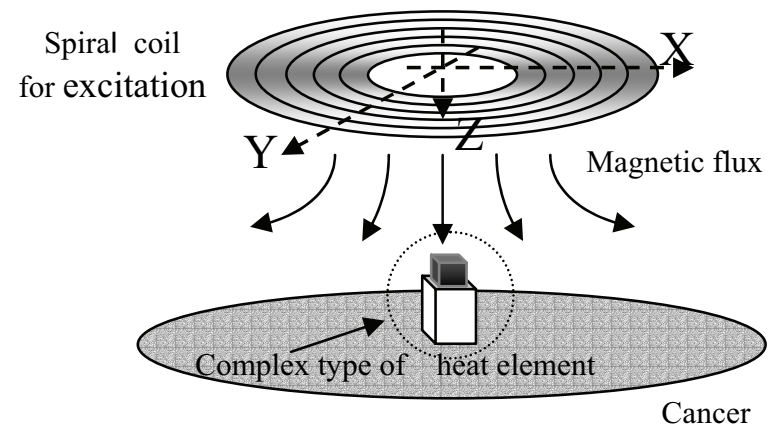

Fig. 4 Excitation with a plane-type spiral coil.

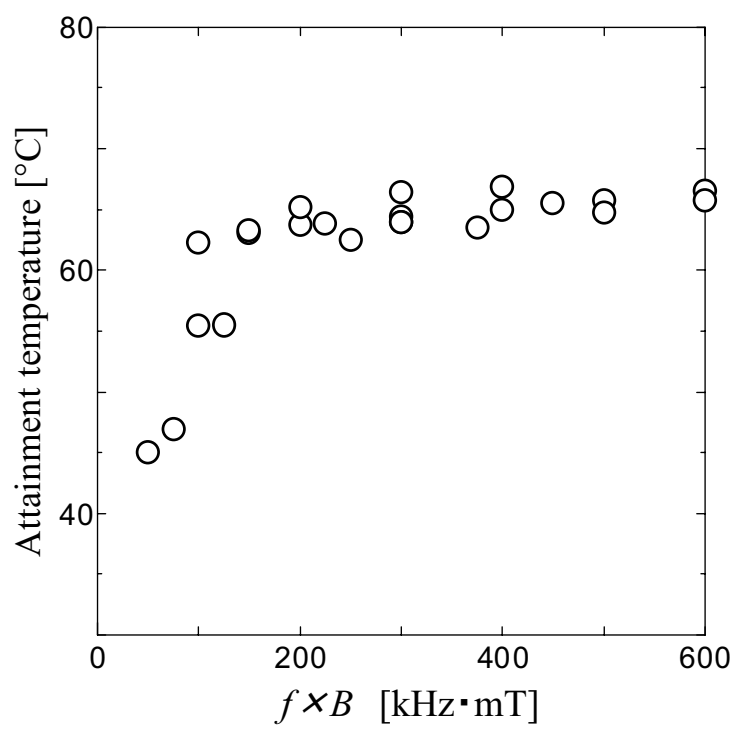

Fig. 5 Temperature characteristic of a complex type of heat element. 


\section{2 磁場分布の差異の発熱特性への影響}

ソレノイドコイルによる励磁の場合，コイル内部に一様 磁界を発生させることが出来るが，平面型コイルの場合， 磁界は距離に従って減衰する. そのため, 長さ $10 \mathrm{~mm} の$ 発熱素子を配置する素子両端の磁界は大きく異なる。この ことによる素子発熱特性を検討する.

今回使用した平面型スパイラルコイルは内径 $20 \mathrm{~mm}$, 外 径 $110 \mathrm{~mm}, 50$ turns のものである. このコイルの磁束密 度特性を Fig. 6 に示す。 また, 内部に一様磁界を発生させ るために用いたソレノイドコイルは内径 $60 \mathrm{~mm}$, 長さ 110 mm, 40 turns のソレノイドコイルである.このソレノイ ドコイルの磁束密度特性を Fig. 7 に示す.

本実験では Fig. 6 の 5-15 mm の地点に素子を配置し, 励磁を行うことで, その磁束密度傾斜が, 発熱特性に影響 するか考察する。 また Fig. 7 のソレノイドコイルは中央部 に素子を配置し, 励磁を行うことで, 一様磁界中における 発熱特性を実現している.また, 実験值とともに, 試作し たコイルと同様にモデリングし，コンピュータシミュレー ションを行った結果を併せて表記するものとする.

実験環境としては, 発熱素子を, 断熱材で覆い, 外部か らの熱影響を遮断している。 また, 恒温槽中 $\left(37^{\circ} \mathrm{C}\right.$ 一定 $)$ に 発熱素子とコイルを設置し実験を行っている.

素子表面の発熱温度の測定結果を Fig. 9 に示す.この結 果から, 平面型スパイラルコイルではコイル近傍すなわち 磁束密度が大きい箇所ではソレノイドコイルの場合と比べ, 高い表面温度分布が得られることが分かる. 一方, コイル から離れた磁束密度が減衰している箇所においてもソレノ イドコイルの場合とほぼ同等の温度まで上昇していること が分かる. そのため, 発熱特性として, この磁場勾配が大 きく影響することはないと考えられる.

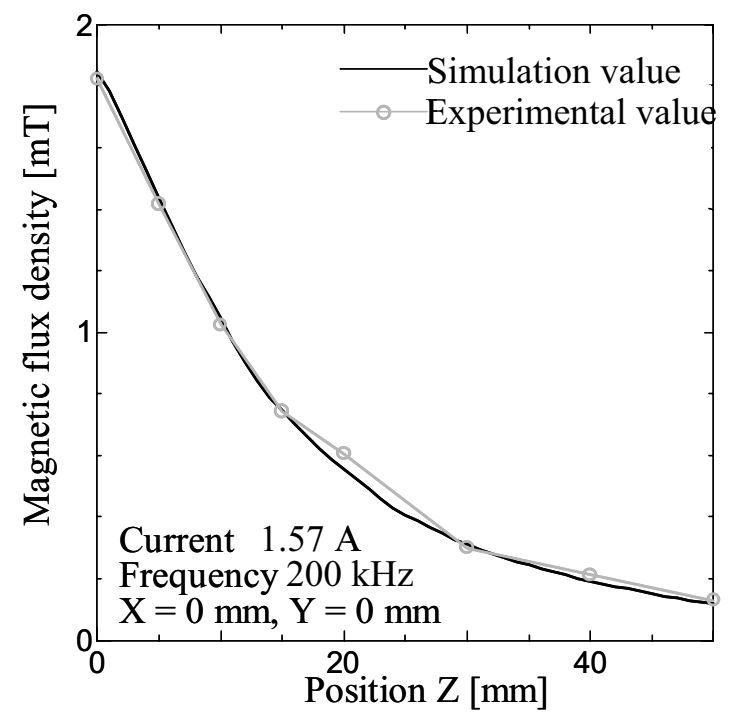

Fig. 6 Magnetic flux density characteristic of plane type spiral coil (Bz)

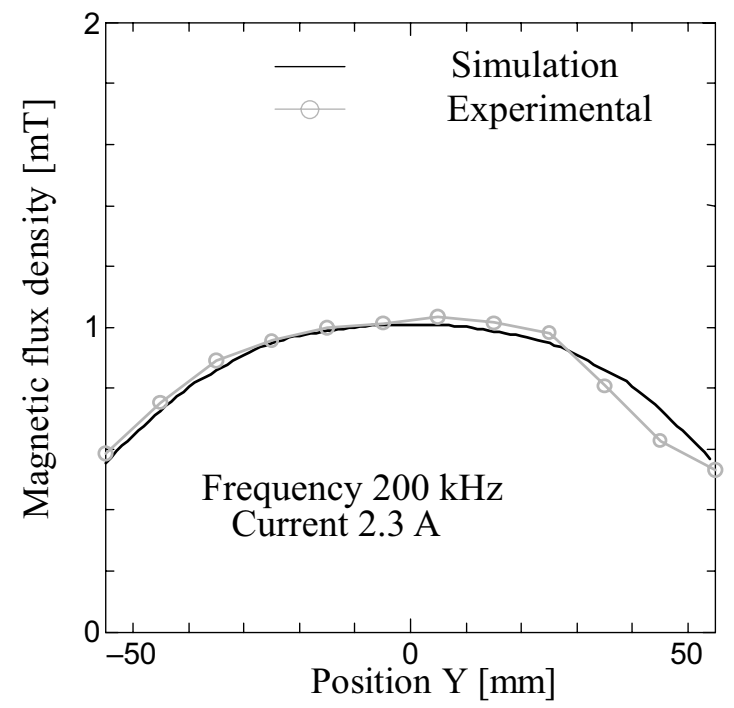

Fig. 7 Magnetic flux density characteristic of solenoidal coil (By).

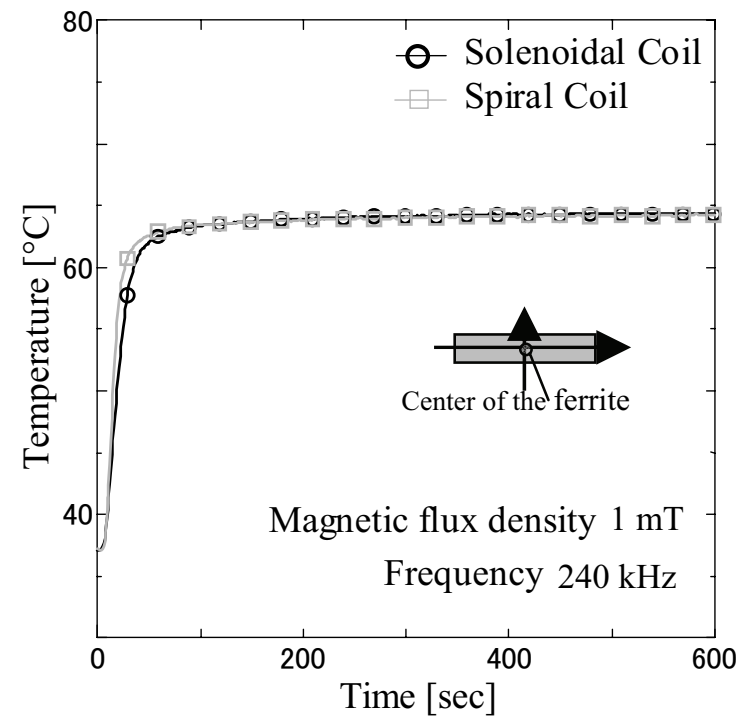

Fig. 8 Temperature characteristic of the center of the element.

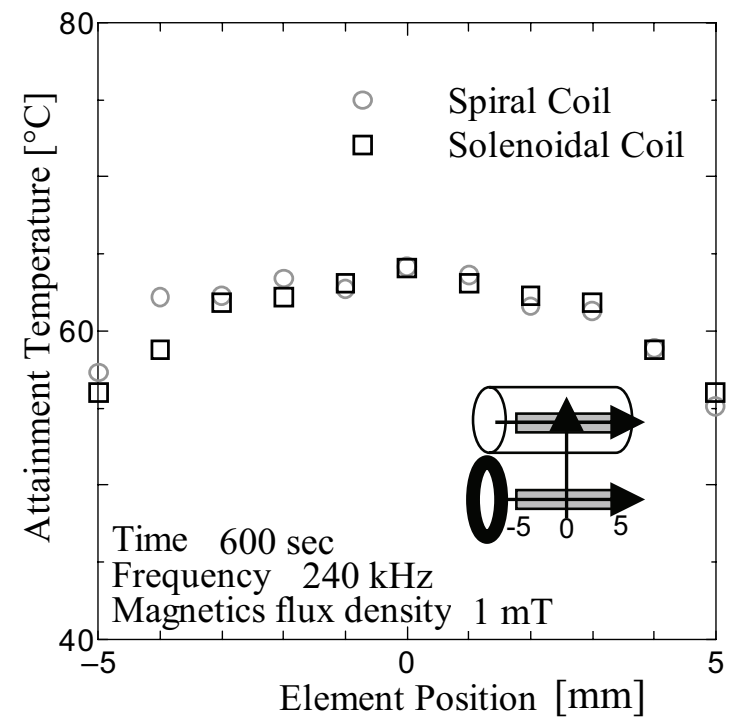

Fig. 9 Temperature characteristic of the surface of the element. 


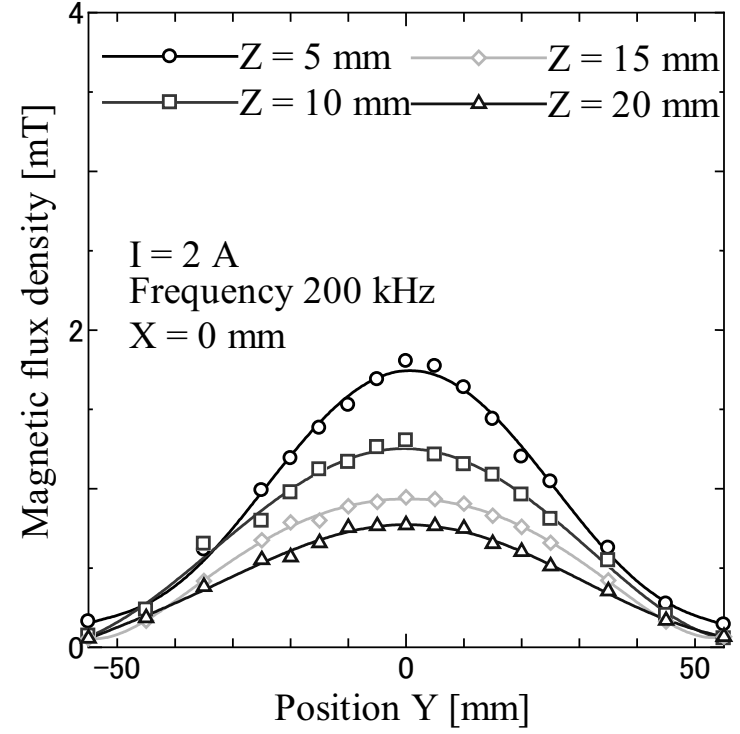

Fig. 10 Magnetic flux density characteristic of a spiral coil (Bz)

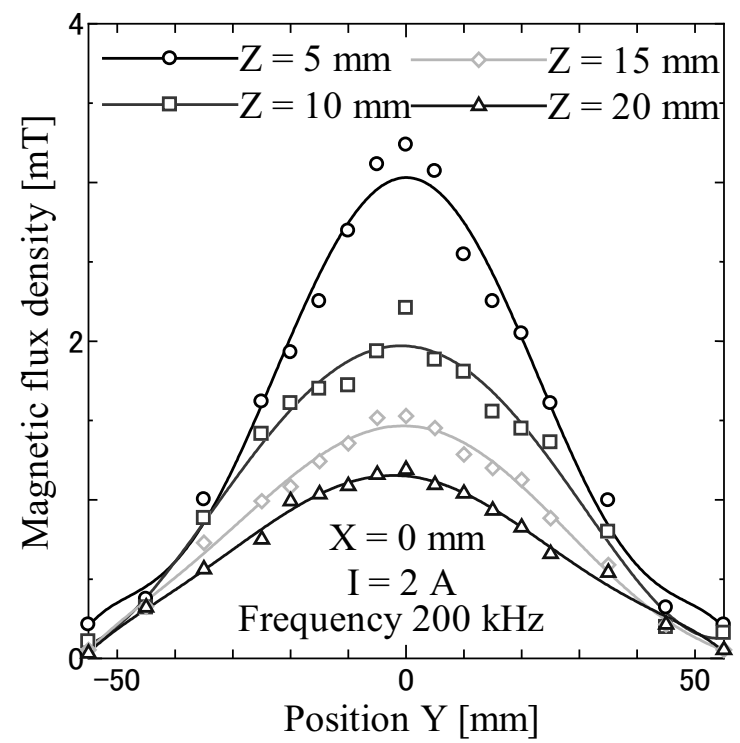

Fig. 11 Magnetic flux density characteristic of a spiral coil with ferrite $(\mathrm{Bz})$

\section{3 磁性体の効果}

平面型スパイラルコイルを励磁素子として想定した場合, コイル面と垂直の両方向へ磁束の放射が起こる.この場合, 発熱素子を励磁するには，片方向への磁場のみを利用する ことになる. また, 平面型コイルの形状を想定した場合, 磁性体を背面に配置することが容易となる。このことから， 平面型コイル背面に磁性体を配置することによって, 磁性 体を配置した方向への磁束の放射を抑えることが可能とな る. 本研究においては, 磁性材料として, $\mathrm{Mn}-\mathrm{Cu}-\mathrm{Zn}$ 系フ エライト $150 \times 150 \times 2.5 \mathrm{~mm}$ のものをコイル背面に配 置している。 また, 磁性体を平面型スパイラルコイルの背 面に配置した場合と配置しない場合の同電流值における磁 束密度特性の変化を Fig. 10, Fig. 11 に示す.このことよ
り, 磁性体を背面に配置する効果によって磁路を変化させ, 同電流值において, 高い磁束密度を確保することが可能で ある. すなわち低電流值において強磁界の発生が可能であ り，簡素な励磁システムを実現する上で有用である．特に 装置の小型化を図る場合などでは，同等の磁束密度を得る ために必要な電流值の軽減が可能である.

\section{4. 結言}

高温ハイパーサーミア発熱素子を浅部腫瘍に適用するこ とを想定した。そのため，コイル近傍に強磁界を発生させ ることを前提とし, 平面型スパイラルコイルの試作を行い, そのコイルによって作り出される近傍磁界を用い，素子の 励磁加温を行った. 平面型コイルでは, 距離によって磁束 密度が急激に減衰するため, 磁場勾配が複合型発熱素子の 発熱特性に影響するか，検討した。その結果，発熱特性は 低下寸ることはなかった。これによって，表在性腫瘍など 浅部の腫瘍に対し，平面型スパイラルコイルでの励磁が悪 影響を及ぼすことはなく，圧迫感の減少などの点での有用 性を見出すことができた，また，平面型コイルの構成にす ることによって磁性体の配置が容易に行うことができる. その効果，磁束の指向性を高めることができ，同電流での 高磁束密度を確保できるため, 励磁電流值を軽減できる. そのため, 励磁装置の小型化を図る上でコイル自体を小さ く設計可能となる。.また，この発熱素子の特性として，角 度ずれへの対応を考慮した場合, 平面型スパイラルコイル において作られる磁場分布の方が，ずれ方向への磁場が存 在するため，角度ずれに対応できる可能性がある．

また，本検討では，主に体の浅部を中心に検討を行って いる．本研究で述べた励磁コイルを含む励磁構成を小型の ユニットとして実現し, 利便性を高める必要がある.また, 腫瘍は体のどの部位にでも存在する可能性がある。そのた め, 浅部腫瘍に対する励磁ユニットの試作とともに体深部 の腫瘍に対して, 励磁加温可能な励磁構成の設計も今後の 課題である.

謝辞 本研究の一部は文部科学省科学研究費「若手研究 $\mathrm{A}$ によった.

\section{References}

1) K. Murakami, and H. Matsuki, Thermosensitivity Magnetism Applied Engineering., pp. 1-33, and 135-140. (Baifukan, Tokyo, 1993)

2) H. Matsuki and K. Murakami, IEEE Trans. Magn., 21, 1927 (1985)

3) K. Murakami, and H. Matsuki, JARECT, 21, 1986

4) F. Sato, M. Jojo, H. Matsuki, T. Sato, M.Sendoh, K. Ishiyama, and K. I. Arai, IEEE Trans. Magn., 38, 3362 (2002).

5). F. Sato, N. Suzuki, J. Shimizu, H. Matsuki, and T. Sato, IEEE Trans. Magn., 40, 2967 (2004)

6) Y. Sawaya, N. Suzuki, F. Sato, H. Matsuki, S. Aiba, and T. Sato, IEEE Trans. Magn. , 41, 4161 (2005)

\section{6年10月19日受理，2007年5月16日採録}

